\title{
THE EVALUATION OF BUSINESS RECEIVABLES USING COSO, RECEIVABLE TURNOVER (RTO), AVERAGE COLLECTION PERIOD (ACP), AND AGING OF ACCOUNT RECEIVABLE (AAR) INTERNAL CONTROL APPROACH MODELS (Case Study at PT Voltech Pratama Semarang)
}

\author{
Saifudin ${ }^{4}$ \\ Miftachus Sa'adah \\ Faculty of Economics, Semarang University (USM)
}

\begin{abstract}
Account Receivables are one important thing of assets. The increase and decrease in account receivables affects the company's operational cash flows directly. Therefore, internal control is needed for every company. The existence of good and regular internal control in managing receivables, the company leadership will obtain reports that are useful to increase the effectiveness of the company.

This research was conducted at PT Voltech Pratama Semarang starting from October to November 2018. The type of research used was descriptive type of research, the type of data used was primary data and secondary data. This research is a research that uses a qualitative descriptive approach, and the analysis technique that will be carried out is a comparative descriptive analysis. Step analysis with data reduction, data presentation, and conclusion drawing.

Based on the research that the researchers did, it can be concluded that the internal control of the account receivable applied at PT Voltech Pratama Semarang has been running quite effectively where the company management has applied the basic concepts and principles of internal control. Seen from the receivable turn over (RTO), average collection period (ACP), and aging account receivable (AAR), PT Voltech Pratama has improved its receivables performance.
\end{abstract}

Keywords: Internal Control, Account Receivables, COSO, Receivable Turn Over, Average Collection Period

\section{INTRODUCTION}

In today's modern era, globalization is not only influential in the field of technology, but globalization is also experienced in the economic field. In Indonesia, the impact of globalization on the economic field can be seen from the growing of many companies, both small and large companies, as well as domestic and foreign companies. The objectives of each companies are of course the same, namely to get the maximum benefit or profit.

One of the company's operating activities which becomes an important factor in business is sales because sales are the source of income for the company. Sales can be done in cash or credit. According to Widiasmara (2014), companies generally prefer cash sales rather than credit, but competitive pressures have forced most companies to offer credit.

\footnotetext{
${ }^{4}$ Saifudin@usm.ac.id; Faculty of Economics, University of Semarang
} 
The reason for a company to do credit sales is to increase sales volume in a certain period and as a strategy to increase market share. With the credit sales, it will give rise to the name of business receivable or trade receivables which are an important part of assets on the balance sheet. The higher the credit sales made by the company, the higher the receivables that exist in the company. Therefore the companies that make credit sales need a reliable internal control system to minimize the risk of uncollectible receivables.

Internal control as a process carried out by the board of commissioners, management and other personnel entities that are designed to provide adequate confidence in achieving the following three categories of objectives: (a) reliability of financial report, (b) effectiveness and efficiency of operations, and (c) compliance with applicable laws and regulations (IAPI, 2011) in Agoes (2016).

The need for internal control within the company is intended that receivables can be collected as expected by the company. However, there is possibility that there are receivables that cannot be collected, causing losses to the company. This loss in accounting is referred to as uncollectible account expense, doubtful account expense, or bad debt expense (Pratama Dera et al., 2016).

The existence of good and regular internal control in managing receivables, the company leaders will obtain useful reports to improve the effectiveness of the company, also assist in deciding policy and accountability in leading the company. Internal control of sales is expected to create effective control activities for the company.

Formulation of the Problem

1. What is the implementation of the internal control system for business receivables at PT Voltech Pratama?

2. What is the evaluation result of uncollectible receivables using the receivable turn over, the average collection period, and the aging of account receivable approaches at PT Voltech Pratama?

\section{LITERATURE REVIEW}

\section{Receivable}

Business receivable is one of the accounts that is used as a benchmark in the company's income statement, including very important and useful for every company engaged in services. Business receivables are able to produce a report on the profits earned by each company, both as current receivable and non-current receivable (Gunawan et al., 2017). According to Farah Margaretha (2011) in Widiasmara (2014), "Receivables are assets or wealth that arise as the result of carrying out credit sales". From some of the above meanings, it can be concluded that receivables are the rights or claims of the company to the client or customer for the sale of goods or services in credit.

\section{The Classification of Receivable}

The classification of receivable is done to facilitate the recording of transactions that affects it. According to Rudianto (2012) in Widiasmara (2014) based on the type and origin of the receivable in the company, receivable can be classified into two groups, namely:

a. Business receivable

b. Non-business receivable

\section{The Recognition of Receivable}

The recognition of business receivable occurs if the company sells products in credit or provides services but no payment has been made to the company. The term recognition itself means "the process of forming a post that meets the definition of elements and criteria for recognition in the balance sheet or income statement" (Indonesian Accounting Association, 
2004) in Widiasmara (2014). Recognition of business receivable is often related to revenue recognition. Because revenue recognition is generally recorded when the process of generating profits has been completed and cash is realized or can be realized, then receivables coming from the sale of goods are generally recognized when the ownership rights to the goods are transferred to the buyer.

\section{The Loss of Uncollectible Receivable}

Kieso et al. (2012) in Pratama Dera et al. (2016) state that uncollectible business receivables are income losses that require, through proper journal entries in accounts, decreases in receivable assets and decreases related to profit and shareholder equity. Income losses and decrease in profits are recognized by recording the doubtful receivable expense (or uncollectible receivables). The expense of uncollectible receivable is a cost for sellers who give credit.

\section{The Removal of Receivable}

Baridwan (2004) in Singal and Victorina (2015), the method of receivable removal is a business receivable that is impossible to collect, such as the debtor is bankrupt, dies, etc. must be written off so that it will be a cost to the company. To record the removal of business receivable can be done by using two methods, namely:

a. Direct Method of Removal (Direct Method)

b. Backup Method (Allowance Method)

\section{The Internal Control}

Internal control is defined as a process, which is influenced by human resources and information technology systems, which are designed to help organizations achieve a certain goal or objective (Widiasmara, 2014).

\section{The Internal Control on Business Receivable}

In Widiasmara's research (2014) Internal control on business receivable is as a preventive measure for the safety of business receivable from the possibility of uncollectible receivable, late collection and misuse of receivable by the employees. Judging from the way of the preventive management approach, there are three common control areas at which point actions can be taken to realize control of receivable. The three areas are:

1. Provision of trade credit

2. Collections

3. Determination and implementation of appropriate internal control.

\section{The Elements of Internal Control}

According to Mulyadi (2001), there are four main elements that must be met to create a satisfactory Internal Control system within the company, as follows:

1) Organizational structure is a framework for functional assignment to organizational units formed to carry out the main activities of the company. The organization of each company is different, depending on the type of the company.

2) The authority system and recording procedures that provide sufficient protection against wealth, debt, income and costs. In organizations, each transaction only occurs on the basis of authorization from those who have the authority to approve the transaction. Therefore in the organization a system that regulates the distribution of authority for the authorization of each transaction execution must be established. 
3) Healthy practice in carrying out the duties and functions of each part of the organization. A good organizational structure, adequate system of authority and recording procedures, must be supported by sound practices so that the implementation it can run well.

4) Employees whose quality are in accordance with their responsibilities.

5) Additional Supervision

\section{The Internal Control Elements}

According to Sanyoto (2009) the internal control elements of the COSO (Committee of Sponsoring Organization) model include the following:

1) Control Environment

2) Risk Assessment

3) Control Activities

4) Information and communication

5) Monitoring

\section{The Characteristics of Strong Internal Control}

Amin Widjaja Tunggal (2013) describes the characteristics of strong internal control are:

1) Competent and honest employees, including mastering accounting, tax regulations and capital market regulation standards.

2) Transactions are authorized by authorized officials (valid transactions).

3) Transactions are properly recorded (the amount, estimation and accounting treatment).

4) Separation of duties that take the initiative to arise a transaction that records and saves.

5) Access to assets and company records in accordance with the functions and duties of those who record and save.

6) Periodical comparisons between balances according to books with physical amounts.

The above characteristics must meet 3 effective control criteria, namely:

1) Preventive Control

2) Detective Control

3) Corrective Control

\section{The Objectives and Benefits of Control of business Receivable in Minimizing the Risk of Uncollectible Receivable}

The control of receivable is intended as an action to save business receivable from the risk of uncollectible receivable, late collection, and employees who abuse the receivable. In addition, the existence of receivable actually has the purpose of increasing the sales volume of the company, with the increase in sales the company will get benefit. However, the risk of uncollectible receivables can be detrimental to the company, for which the need for internal control to evaluate the company in order to make improvements for the future. According to Mulyadi (2001) the objectives of the internal control system are:

1) Maintainung the organizational wealth

2) Checking the accuracy and reliability of accounting data

3) Encouraging efficiency

4) Encouraging the compliance of management policies.

\section{The Analysis of Receivable Period}

The ratio describes a relationship or balance between a certain amount and the number of others by using an analysis tool in the form of this ratio, which can explain or give an overview to the analyst about the good or bad situation or financial position. The financial ratio to assess the investment in receivable is as follows: 


\section{The Receivable Turnover Ratio}

According to Darsono (2006) Receivable as an element of working capital is in a spinning condition, namely from cash, commodity processes, sales, receivable, back to cash. The faster the receivable turnover, the better the financial condition of the company. Receivable turnover can be presented by the calculation: net sales in credit divided by the average of receivable. Calculating Receivable Turnover (Widiasmara, 2014) where, to calculate the average receivable is:

$$
\text { Average of receivable }=\frac{\text { Net Credit Sales }}{\text { Average of receivable }}
$$

First Balance of Receivable + Last Balance of Receivanle

Average of receivable $=$

2

\section{The Average Collection Period}

The high and low receivable turnover has direct effect on the size of the capital invested in the receivables. The higher the turnover, the faster the turnover, which means the shorter the bounded time of capital in receivable. So to maintain a certain net credit sales with the increasing turnover, the smaller amount of capital invested in the receivables is needed. Calculating the average receivable period (Average Collection Period) (Widiasmara, 2014) is as follows:

$$
\text { Average Collection Period }=\frac{360 \text { days }}{\text { receivable turnover }}
$$

\section{The Aging of Account Receivable (AAR)}

According to Widiasmara (2014) Aging of Account Receivable is a credit monitoring technique that uses a schedule that shows the percentage of the total remaining account receivables that have not been paid for a certain period of time. The purpose of this technique is to know the problem correctly. For example, a company has net 30 with ACP (minus receipt, processing and disbursement) 50 days, meaning that the company's ACP is too old. 


\section{The Research Flow}

This research has the following research flow:

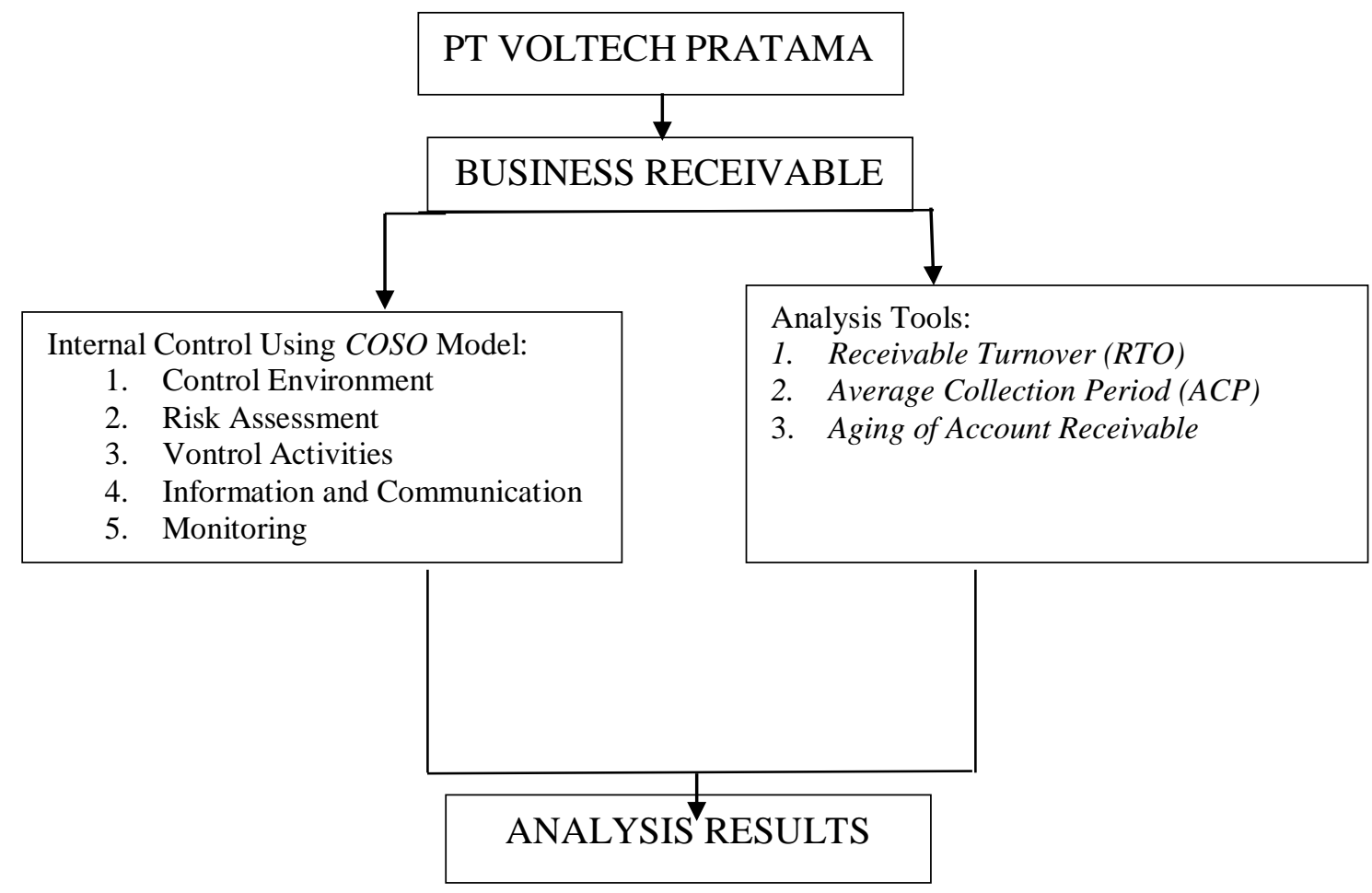

\section{RESEARCH METHOD}

This research was conducted by using descriptive research. While the research approach used qualitative approach. This research is intended to evaluate internal control over the business receivable applied by the company where the research is conducted. The internal control investigated is related to the control environment, risk assessment, control activities, information and communication, as well as monitoring. Therefore, the research used is a qualitative approach where the data used are not only in the form of digits but also involves qualitative data from observations and interviews. From this study it can be seen whether internal control to minimize the risk of uncollectible receivable has been running effectively or not.

The types of data used in this study are primary and secondary data. The primary data used in this study were obtained from the results of interview and observation at PT Voltech Pratama. This study uses secondary data in the form of data that have been compiled by the company, namely the company's development history, job description, and organizational structure. In addition, the secondary data compiled in this study are also in the form of reports on business receivable, uncollectible receivable, and credit sales for the last three years, namely 20152017.

In conducting research at PT Voltech Pratama, the complete and accurate data are needed to provide good and useful information. For that reason the researchers tried to collect data by conducting interview and observation. 
The steps in this analysis are:

1. Collecting data both in the form of documents and from the results of observations and interviews about the implementation of internal control on receivable.

2. The results of the observation and interview are documented in the form of structured writing before analysis has been done.

3. Analyzing the application of accounting information system elements to the object to be examined, namely:

a. Analyzing the organizational structure and the division of job descriptions in each sections.

b. Analyzing internal control on receivables.

c. Analyzing financial statements.

4. Providing suggestions for changes to internal control on receivables that still contain weaknesses.

5. Drawing conclusion and suggestion from data processing and comparison that have been conducted.

\section{RESULT AND DISCUSSION}

\section{The Internal Control of the COSO Model at PT Voletch Pratama The Control Environment}

The Control Environment at PT Voltech Pratama is good enough. Every rules that has been made by the management is carried out by the employees and the employees know their respective duties and responsibilities. There has been separation function between the functions of the financial department, the AR department, with the bookkeeping department. However, in the sales department there is one who has double task that are collecting customer receivables that is not in accordance with the existing job desc, the doubling task is caused by a weak customer who does not want to make a payment vua transfer.

\section{The Risk Assessment}

The risk assessment at PT Voltech Pratama regarding receivables has been implemented well with the analysis of lending carried out by PT Voltech Pratama, which is not directly providing payment tempo for the customers, but it is monitored in advance by making cash purchases for customers then continued with the field survey stage done by sales. Moreover there is a credit limit and a customer credit list, with the credit limit for customers and followup if the receivables are difficult to collect. Although the company does not set aside for uncollectible receivable because during the operation the receivable can always be collected. The impact of the existence of uncollectible receivable will directly affect the company's operational activities at the cash flow.

\section{The Control Activities}

Control activities at PT Voltech Pratama runs well both from the recording of receivable and the collection of receivable by using receivable reconciliation.

\section{The Information and Communication}

Information and communication at PT Voltech Pratama company is also good because of rge existence of communication between the superiors and subordinates to inform various company activities. For the operations, it has also used a computer system to make it more effective.

\section{The Monitoring}


Monitoring at PT Voltech Pratama is quite good, seen from the evaluations carried out by the company, including being more selective in choosing customers, finding out what makes the receivables difficult to be collected, and applying lock system or locking the applicable system for customers who want a return order but the receivables are already due and have not been paid off.

The Evaluation of Uncollectible Receivables using the Receivable Turnover (RTO), Average Collection Period (ACP), and Aging of Account Receivable Approaches

The Receivable Turnover (RTO)

The receivables owned by a company have close relationship with credit sales volume.

Calculating Receivable Turnover Ratio:

Net Credit Sales

Receivable Turnover $=$

The Average of Receivable

Early Balance of Receivable + Last Balance of Receivable

The Average of Receivable $=$

The results of the receivable turnover are as follows:

a. 2015

3.489.273.082

Receivable Turnover $=\frac{626.899 .020}{6,57}$

b. 2016

Receivable Turnover $=\frac{427.470 .887}{334.716 .794}=1,28$

c. 2017

2.297.684.607

Receivable Turnover $=$ $=5,22$

440.144 .996 
The above RTO results can be seen through the following table:

Table 1

The Calculation Result of Receivable Turnover (RTO)

\begin{tabular}{|c|c|c|c|c|}
\hline Year & $\begin{array}{c}\text { Net Credit Sales } \\
(\mathbf{R p})\end{array}$ & $\begin{array}{c}\text { The Average of } \\
\text { Receivable (Rp) }\end{array}$ & $\begin{array}{c}\text { RTO } \\
\text { (Times) }\end{array}$ & $\begin{array}{c}\text { Changes in } \\
\text { RTO }\end{array}$ \\
\hline 2015 & 3.489 .273 .082 & 626.899 .020 & 5,57 & - \\
2016 & 427.470 .887 & 334.716 .794 & 1,28 & $(4,29)$ \\
2017 & 2.297 .684 .607 & 440.144 .996 & 5,22 & 3,94 \\
\hline
\end{tabular}

Source: PT Voltech Pratama, 2018

The table above proves that the company is trying to improve its receivable performance by increasing its credit sales and reducing to a minimum the amount of receivables that have been due date, because basically the higher the level of the receivable turnover, the better the management of receivables, moreover the high receivable turnover means the shorter the time of the capital is bound in the receivables.

\section{The Average Collection Period (ACP)}

This ratio serves to find out the average days needed to collect receivables and convert them into cash.

Calculating the Average Collection Period

$$
\text { Average Collection Period }=\frac{360 \text { Days }}{\text { Receivable Turnover }}
$$

The calculation results of the ACP are as follows:

a. 2015

$$
\mathrm{ACP}=\frac{360}{5,57}=65
$$

b. In 2016

$\mathrm{ACP}=\frac{360}{1,28}=282$

c. In 2017

$$
\mathrm{ACP}=\frac{360}{5,22}=69
$$


The ACP Calculation results above can be seen in the following table:

Table 2

The Calculation Results of Average Collection Period - ACP

\begin{tabular}{|c|c|c|c|}
\hline Year & RTO (Times) & ACP (Days) & $\begin{array}{c}\text { Changes in } \\
\text { ACP }\end{array}$ \\
\hline 2015 & 5,57 & 65 & - \\
2016 & 1,28 & 282 & 217 \\
2017 & 5,22 & 69 & $(213)$ \\
\hline
\end{tabular}

Source : PT Voltech Pratama Data, 2018

From the results of the table above, the level of the Average Collection (ACP) of the company is very much influenced by the level of the Receivable Turnover (RTO) of the year concerned. The greater the level of the company's RTO, the better the ACP value. The best Average Collection Rate (ACP) of the company is in 2015, which is 65 days, where the receivable turnover rate is also high. As for the lowest ACP level of the company is in 2016, where the ACP level reaches 282 days, with a low receivable turnover rate of 1.28 times.

The Aging of Account Receivable (AAR)

Table 3

The Calculation Results of Aging of Account Receivable - AAR $*$ in Percentage

\begin{tabular}{|l|l|l|l|}
\hline \multicolumn{1}{|c|}{ Bucket } & \multicolumn{1}{|c|}{$\mathbf{2 0 1 5}$} & \multicolumn{1}{c|}{$\mathbf{2 0 1 6}$} & \multicolumn{1}{c|}{$\mathbf{2 0 1 7}$} \\
\hline $0-30$ & 0,00 & 96,47 & 24,04 \\
$31-60$ & 0,00 & 0,00 & 63,13 \\
$61-90$ & 0,00 & 0,00 & 9,40 \\
$>90$ & 100,00 & 3,53 & 3,44 \\
\hline
\end{tabular}

Source : PT Voltech Pratama Data, 2018

The Aging of Account Receivable table above shows that the Aging of Account Receivable ratio has improved aging from year to year. This shows that the billing system carried out by PT Voltech Pratama has improved from year to year. It also shows that the internal control carried out by PT Voltech Pratama shows good progress from year to year.

\section{CONCLUSION}

Based on the results of the discussion on internal control of receivables to minimize the risk of uncollectible receivables at PT Voltech Pratama, the internal control system at PT Voltech Pratama has been quite effective seen from the control environment, the risk assessment, the control activities, the information and communication, and the monitoring. While in terms of improving the performance of receivables, it can be seen from the application of Receivable Turnover (RTO), Average Collection Period (ACP) and Aging of Account Receivable (AAR), which shows that the billing system carried out by PT Voltech Pratama has improved from year to year. It also shows that the internal control carried out by PT Voltech Pratama shows good progress from year to year. 


\section{SUGGESTIONS}

The researchers hope that the next study can discuss the same theme but conduct the research with different method, for example with quantitative method, or can still use the case studies but the discussion is more extensive.

\section{BIBLIOGRAPHY}

Agoes, Sukrisno. 2016. Auditing. Jakarta : Salemba Empat

Darsono. 2006. Manajemen Keuangan. Jakarta : Diadit Media

Gunawan, Rendi, dkk. 2017. Analisis Sistem Pengendalian Internal Atas Piutang Untuk Meminimalkan Jumlah Piutang Tak Tertagih Pada PT. MNC Kabel Mediakom Cabang Surabaya. Jurnal Ekonomi Akuntansi Vol. 3. Issue. 3

Indriantoro, Nur, Bambang Supomo. 2014. Metodologi Penelitian Bisnis Untuk Akuntansi dan Manajemen. Yogyakarta:BPFE

Keown, Arthur J, et al. 2002. Manajemen Keuangan. Salemba Empat, Jakarta

Khaerunnisa, Amelia, dkk. 2017. Pengaruh Sistem Pengendalian Internal Penjualan Kredit Terhadap Piutang Tak Tertagih Pada PT. Mensana Aneka Satwa. E-Journal Universitas Pakuan Bogor (Tidak Dipublikasikan)

Miles, M.B \& Huberman. 1992. Analisis Data Kualitatif. Jakarta : Universitas Indonesia Press

Mulyadi. 2001. Sistem Akuntansi. Jakarta : Salemba Empat

Munawir. 2007. Analisis Laporan Keuangan. Yogyakarta : Edisi Empat, Liberty

Pratama Dera, Arya dkk. 2016. Analisis Efektivitas Sistem Pengendalian Internal Piutang Dan Kerugian Piutang Tak Tertagih Pada PT. Surya Wenang Indah Manado. Jurnal EMBA Vol. 4 No. 1 Maret 2016, Hal 1498-1508

PT Voltech Pratama. 2018. Company Profiele PT Voltech Pratama. Semarang: PT Voltech Pratama

PT Voltech Pratama. 2018. Job Description PT Voltech Pratama. Semarang: PT Voltech Pratama

Singal, Christian Richo dan Victorina Z. Tirayoh. 2015. Analisis Pengendalian Interna Piutang Usaha Pada Developer Grand Kawanua International City. Jurnal EMBA Vol.3 No.1 Maret 2015, Hal.286-296

Soemarso. 2010. Akuntansi Suatu Pengantar. Edisi 5. Cetakan keenam. Jakarta: Rineka Cipta.

Suharto. 2017. Analisis Sistem Pengendalian Internal Atas Piutang Usaha Pada PT. Wahana Ottomitra Multiartha (WOM), Tbk Cabang Kota Lubuklinggau. Prosiding Seminar Nasional AIMI ISBN: 978-602-98081-7-9

Widiasmara, Anny. 2014. Analisis Pengendalian Intern Piutang Usaha Untuk Meminimalkan Piutang Tak Tertagih (Bad Debt) Pada PT.Wahana Ottomitra Multiartha, Tbk Cabang Madiun. Modernisasi, Volume 10, Nomer 2 